\title{
Genetically Engineered Hematopoietic Stem Progenitor Cells
}

National Cancer Institute

\section{Source}

National Cancer Institute. Genetically Engineered Hematopoietic Stem Progenitor Cells. NCl Thesaurus. Code C119988.

Gene modified hematopoietic stem progenitor cells (HSPCS). 